\title{
Pengujian Efek Fisher:Pengaruh Ekspektasi Inflasi Dan Kegiatan Ekonomi Terhadap Tingkat Bunga Nominal Di Indonesia
}

\author{
Dian Pratiwi ${ }^{1)}$, Muhammad Imron ${ }^{2)}$, Setyo Agung $P^{3)}$ \\ ${ }^{11,2) 33}$ Dosen Fakultas Ekonomi Universitas Merdeka Madiun
}

\begin{abstract}
The purpose of this paper is to investigate the effect of inflation and economic activity to nominal rate. A model based on Fisher Effect and used time series data for the period of 2010-2012. The finding suggests that expected inflation and economic activity have significant effect on the nominal rate as dependent variable. As the limitation, the data used in this paper are limited to three years time series data. A more detail analysis would use data more completely. The findings of the study clearly demonstrate the Fisher Effect theory.
\end{abstract}

Keywords: Fisher Effect, Expected Inflation, Economic Activity, Nominal Rate

\section{PENDAHULUAN}

Kebijakan $\mathrm{BI}$ rate yang dilakukan dalam rangka mengendalikan inflasi akan diikuti oleh sektor perbankan dalam menentukan suku bunga simpanan ataupun pinjaman. Ketika suku bunga simpanan naik, hal ini akan mendorong masyarakat menunda kegiatan konsumsi karena memilih menyimpan dana di bank. Kenaikan suku bunga simpanan akan meningkatkan biaya dana bank.

Suku bunga dan inflasi merupakan dua hal yang saling berkaitan. Dari dua hal yang menjadi perhatian ini maka muncullah pemikiran oleh Irving Fisher, seorang ekonom dari Amerika dengan hipotesis Fishernya yaitu: efek Fisher, hubungan antara suku bunga dan inflasi. Di mata Fisher, keduanya bersama-sama diikat oleh berbagai tuntutan ekonomi. Hubungan ini begitu kuat bahwa jika inflasi naik, suku bunga akan naik dalam jumlah yang sama.

Efek Fisher sering digunakan untuk memahami tingkat bunga aktual dan nominal. Salah satu contoh dari hal ini akan mempertimbangkan tingkat inflasi suatu negara. Jika tingkat inflasi suatu negara meningkat sebesar 1 persen, efek Fisher menyatakan bahwa suku bunga juga akan naik sebesar 1 persen.

Studi mengenai Efek Fisher atau hubungan antara tingkat bunga dengan inflasi sebelumnya sudah banyak dilakukan. Seperti yang telah dilakukan Mishkin (1981) di Australia.hasil penelitian menunjukkan bahwa Efek Fisher muncul pada sampel yang inflasi dan suku bunganya mengalami stochastic trend sehingga keduanya memiliki korelasi yang kuat.

Dengan memperhatikan kondisi, permasalahan dan karakteristik perekonomian nasional tersebut, permasalahan selanjutnya adalah bagaimana mewujudkan dan menjaga kestabilan nilai rupiah (yang tercermin pada tingkat inflasi) guna mempercepat usaha pemulihan ekonomi nasional. Sehubungan dengan hal tersebut, maka merupakan suatu hal yang menarik untuk mendiskusikan dan meneliti mengenai tingkat suku bunga nominal serta variabel-variabel yang mempengaruhinya. Hal ini didasarkan pada alasan bahwa apabila pemerintah menetapkan inflasi sebagai sasaran akhir, seperti yang dikemukakan di atas, pengendalian inflasi akan sangat 
tergantung pada penggunaan instrumen suku bunga.

Selain ekspektasi inflasi seperti yang telah disebutkan di atas, dalam penelitian ini perlu ditambahkan variabel kegiatan ekonomi sebagai salah satu faktor yang mempengaruhi tingkat suku bunga nominal. Hal ini sedikit berbeda dengan teori yang dikemukakan oleh Fisher yang menyatakan bahwa ekspektasi inflasi mempunyai pengaruh terhadap suku bunga nominal dengan asumsi bahwa suku bunga riil konstan, dan ekspektasi inflasi dipakai sebagai satu-satunya variabel independen yang dapat menjelaskan perubahan pada suku bunga nominal.

Asumsi Fisher tersebut tidak sepenuhnya benar bagi perekonomian yang fluktuatif seperti Indonesia, karena suku bunga riil tidaklah konstan, tetapi selalu berubah dipengaruhi oleh fluktuasi perekonomian (business cycles). Pengaruh business cycles terhadap suku bunga riil dapat dijelaskan dengan dua jalur, yaitu melalui pengaruhnya terhadap ekspektasi inflasi dan melalui ekspektasi tingkat bunga riil.

\section{Tujuan Penelitian}

tujuan penelitian ini adalah untuk mengetahui pengaruh ekspektasi inflasi dan kegiatan ekonomi terhadap tingkat suku bunga nominal di Indonesia.

\section{TINJAUAN PUSTAKA \\ Pengertian Suku Bunga}

Menurut Hubbard

(Didy

Laksmono et al, 2001), bunga adalah biaya yang harus dibayar peminjam atas pinjaman yang diterima dan imbalan bagi pihak yang meminjamkan. Suku bunga mempengaruhi keputusan individu terhadap pilihan membelanjakan uang lebih banyak atau menabung untuk membeli rumah. Sementara, Kern dan Guttman (Didy Laksono et al, 2001) menganggap suku bunga merupakan sebuah harga dan sebagaimana harga lainnya maka tingkat suku bunga ditentukan oleh interaksi antara permintaan dan penawaran.

1. Jenis suku bunga yaitu:Suku bunga nominal yaitu Suku Bunga yang dapat di amati di pasaran.

2. suku bunga riil yaitu suku Bunga yang secara konsep di ukur tingkat pengembaliannya setelah dikurangi inflansi.

3. Suku bunga jangka pendek yaitu Suku Bunga yang jatuh tempo (Maturity) satu tahun atau kurang.

4. Suku bunga jangka panjang yaitu Suku Bunga yang jatuh tempo (Maturitty) lebih dari satu tahun. Dalam pasar keuangan di kenal berbagai macam bunga yang disediakan para Debitur untuk melakukan Investasi.

Penentuan Suku Bunga menurut Edward dan Khan (1985) mengindetifikasikan factor penentu suku bunga menjadi dua, yaitu Faktor Internal dan Eksternal. Faktor Internal meliputi pendapatan nasional, jumlah uang beredar (JUB), dan Inflasi yang diharapkan. Sedangkan Faktor Eksternal merupakan penjumlahan Suku Bunga luar negeri dan tingkat perubahan nilai tukar valuta asing yang di harapkan. Adapun penjelasan teoritis mengenai proses penentuan suku bunga yaitu dengan The Monetary Theory atau Likuidity Preference Theory. Dalam teori ini pendekatan moneter dikembangkan oleh ekonom penganut aliran Kynes yang lebih mengutamakan peranan spekulasi dalam membentuk ekspektasi. Argumentasi yang di berikan menurut Kern dan Guttman (1992:4) dalam Laksmono (2001) adalah : "walaupun suku bunga sangat rendah selama masa resesi, orang akan tetap memegang uang di bandingkan menginvestasikannya, sehingga tingkat bunga yang di rencanakan dan tingkat 
investasi yang diperlukan tidak sama dengan kondisi normal ". (laksomono et.al, 2001:130). Argumen tersebut merupakan pijakan dasar bagi pendekatan moneter sehingga pendekatan suku bunga bergantung pada penawaran dan permintaan untuk memegang uang dan unsure spekulatif mendorong adanya ketidakseimbangan jangka panjang. Dalam kerangka teori Keynes, uang dipegang bukan hanya untuk tujuan transaksi dan berjaga2 (Precautionary) semata2, tetapi untuk tujuan spekulatif. Oleh karena itu uang di pegang sebagai alternative terhadap obligasi untuk memperoleh keuntungn jika suku bunga meningkat yang berakibat pada turunnya harga obligasi, sehingga ada kesempatan untuk membeli obligasi pada harga yang lebih menguntungkan. Sebaliknya jika ekspetasi suku bunga akan turun maka harga obligasi akan meningkat,orang akan lebih cenderung memegang obigasi dari pada uang.

\section{Teori Ekspektasi rasional}

Teori ekspektasi rasional atau sering pula disebut sebagai teori ekonomi klasik baru ini dikembangkan oleh Robert Lucas, Thomas Sargent, Neil Wallace, dan Robert Barro. Para peneliti ini menekankan peranan ekspektasi dan fleksibilitas harga dan upah dalam perekonomian makro (Samuelson, 1996).

Teori ekspektasi rasional sangat mirip dengan pendekatan klasik terhadap makro ekonomi. Teori ini menyatakan:

1. Masyarakat menggunakan seluruh informasi yang ada

2. Harga dan upah bergerak secara fleksibel

Kedua dalil ini merupakan inti dari revolusi yang dikemukakan oleh teori ekspektasi rasional.

Hipotesis pertama yang menyatakan bahwa masyarakat membentuk perkiran mereka berdasarkan informasi terbaik yang tersedia. Dengan asumsi ini, pemerintah tidak dapat membodohi masyarakat. Masyarakat memiliki informasi yang baik dan memiliki akses terhadap inormasi yang sama dengan yang dimiliki pemerintah.

Ekpektasi (harapan atau dugaan) merupakan hal penting dalam kehidupan ekonomi. Hal ini mempengaruhi seberapa besar investor akan membuat pengeluaran untuk investasi barang dan apakah para konsumen akan melakukan pengeluaran atau menabung untuk masa depan. Tetapi cara apa yang paling bijaksana untuk melakukan perkiraan-perkiraan dalam perekonomian? Para teoritikus ekspektasi rasional menjawab pertanyaan ini dengan hipotesis ekspektasi rasional. Sesuai dengan ekspektasi rasional, ramalan-ramalan menjadi tidak bias dan didasarkan pada seluruh informasi yang tersedia.

Untuk memulainya, hipotesis ekspektasi rasional menganggap bahwa masyarakat membuat ramalan-ramalan yang tidak bias. Lebih jauh, hipoteis tersebut mengasumsikan bahwa masyarakat menggunakan seluruh informasi yang tersedia dan teori-teori ekonomi. Hal ini menunjukkan bahwa masyarakat memahami bagaimana perekonomian bekerja dan apa yang dilakukan pemerintah. Jadi, teori ekspektasi rasional mengasumsikan bahwa masyarakat akan mengantisipasi bentuk perilaku pemerintah dan bertindak dengan sesuai.

Pokok pertama yang penting tentang ekspektasi rasional adalah bahwa pemerintah tidak dapat mengelabuhi masyarakat tentang sistematika kebijakan ekonomi.

Hipotesis kedua menyatakan bahwa harga dan upah adalah fleksibel. Asumsi yang umum ini secara sederhana mempunyai arti bahwa harga dan upah disesuaikan dengan 
cepat untuk mengimbangi penawaran dan permintaan. Dengan kata lain, harga-harga fleksibel, dan seluruh pasar mengalami keseimbangan setiap waktu.

Dengan mengombinasikan asumsiasumsi dari ekspektasi rasional dan harga-harga yang fleksibel, para ahli ekonomi makro ekspektasi rasional dapat menunjukkan implikasi-implikasi tertentu yang mengejutkan bagi teoriteori dan kebijakan-kebijakan makroekonomi.

\section{Inflasi}

Menurut Bodie dan Marcus (2001:331) inflasi merupakan suatu nilai dimana tingkat harga barang dan jasa secara umum mengalami kenaikan. Inflasi adalah salah satu peristiwa moneter yang menunjukkan suatu kecenderungan akan naiknya hargaharga barang secara umum, yang berarti terjadinya penurunan nilai uang. Penyebab utama dan satu-satunya yang

memungkinkan gejala ini muncul menurut Teori Kuantitas mengenai uang pada mazhab klasik adalah terjadinya kelebihan uang yang beredar sebagai akibat penambahan jumlah uang di masyarakat.

\section{METODE PENELITIAN}

Untuk memenuhi tujuan penelitian ini, yaitu untuk menganalisa pengaruh ekspektasi inflasi dan kegiatan ekonomi terhadap tingkat bunga nominal dan mendapatkan fungsinya akan digunakan analisa regresi linier berganda untuk pendekatan ekspektasi rasional dengan menggunakan metode Ordinary Least Square (OLS).

Dengan menggunakan alat analisa ini diharapkan dapat memberikan beberapa implikasi teoritis tentang pengaruh ekspektasi inflasi dan kegiatan ekonomi (yang dinotasikan jumlah uang yang beredar (M2)) terhadap tingkat bunga nominal.
Untuk menguji hipotesis bagaimana pengaruh dari variabel bebas (independent variable) terhadap tingkat bunga nominal sebagai variabel terikat digunakan analisis regresi berganda (multiple regression) dengan persamaan kuadrat terkecil (Ordinary Least Square/OLS), dengan menggunakan bantuan program SPSS dengan persamaan dasar sebagai berikut:

$Y=b_{0}+b_{1} X_{1}+b_{2} X_{2}+b_{3} X_{3}+b_{4} X_{4}+e$ Dimana :

$\mathrm{Y}=$ Int3 (suku bunga deposito bank umum 3 bulanan)

$\mathrm{X}_{1}=$ Inflasi periode sebelumnya

$\mathrm{X}_{2}=$ jumlah uang yang beredar

(M2)

$\mathrm{b}_{0} \quad=$ Konstanta regresi

$b_{1}, b_{2},=$ Koefisien regresi

$\mathrm{e} \quad=$ Standart error

DEFINISI OPERASIONAL VARIABEL

1. Tingkat bunga nominal pada periode $t \quad\left(\mathrm{i}_{\mathrm{t}}\right)$ merupakan tingkat bunga nominal yang ditetapkan oleh perbankan dalam hal ini bank umum. Tingkat bunga yang dipakai dalam penelitian ini adalah suku bunga deposito 3 bulan karena dirasa sesuai dengan tingkat bunga nominal dan tidak terdapat unsur profit dari bank, dimana tiap-tiap bank berbedabeda seperti halnya pada tingkat bunga kredit, INT3 (suku bunga deposito 3 bulan).

2. Tingkat inflasi pada periode $t$, yaitu perubahan tingkat harga secara umum dari periode satu ke periode yang selanjutnya. Dalam hal ini peneliti menggunakan tingkat inflasi IHK (Indeks Harga Konsumen).

3. Kegiatan ekonomi yang dinotasikan dari pertumbuhan jumlah uang beredar $\left(\mathrm{GM}_{\mathrm{t}}\right)$, yaitu pertumbuhan jumlah uang yang beredar di masyarakat, baik berupa uang dalam 
arti sempit (M1) maupun uang beredar dalam arti luas (M2). Dalam hal ini peneliti menggunakan pertumbuhan M2 untuk menggambarkan pertumbuhan jumlah uang yang beredar.
Dari hasil pengujian yang dilakukan dengan menggunakan tingkat inflasi tahun sebelumnya dan jumlah uang beredar terhadap suku bunga nominal deposito 3 bulan maka diperoleh hasil sebagaimana table di bawah ini:

\section{PEMBAHASAN}

Tabel 1

\begin{tabular}{|c|c|c|c|c|c|}
\hline \multicolumn{6}{|c|}{ Model Summary } \\
\hline $\begin{array}{l}\text { Mode } \\
\text { I }\end{array}$ & $\mathrm{R}$ & R Square & $\begin{array}{l}\text { Adjusted R } \\
\text { Square }\end{array}$ & $\begin{array}{l}\text { Std. Error of } \\
\text { the Estimate }\end{array}$ & $\begin{array}{l}\text { Durbin- } \\
\text { Watson }\end{array}$ \\
\hline 1 & .940 & .884 & .858 & .13597 & 2.081 \\
\hline \multicolumn{6}{|c|}{ a. Predictors: (Constant), inflasi, m2 } \\
\hline \multicolumn{6}{|c|}{ b. Dependent Variable: int3 } \\
\hline
\end{tabular}

Koefisien determinasi $\left(R^{2}\right)$ untuk melihat seberapakah kemampuan model dalam menerangkan variasi variabel dependen. Nilai koefisien determinasi antara nol dan satu. Nilai yang mendekati satu berarti variabelvariabel independen memberikan hampir semua informasi yang dibutuhkan untuk memprediksi variabelvariabel dependen.
Dari nilai $R$ square $\left(R^{2}\right)$ dapat diketahui besarnya pengaruh inflasi, jumlah uang beredar terhadap suku bunga deposito 3 bulan sebesar $88,4 \%$.

Untuk mengetahui apakah model regresi tersebut di atas sudah benar atau salah maka diperlukan uji hipotesis. Uji hipotesis menggunakan angka $F$ sebagaimana tertera pada table di bawah ini:

Tabel 2

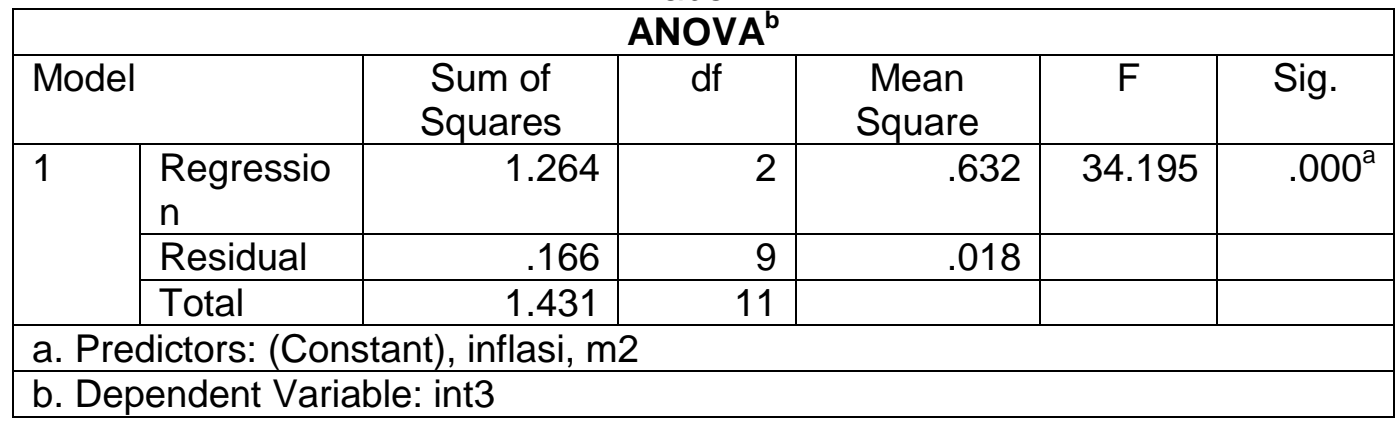

Berdasarkan perhitungan, angka signifikansi sebesar $0,00<0,05$ maka $\mathrm{HO}$ ditolak dan $\mathrm{H} 1$ diterima. Artinya ada hubungan linier antara inflasi, jumlah uang yang beredar dengan tingkat suku bunga deposito 3 bulan. Untuk melihat pengaruh inflasi, jumlah uang yang beredar secara parsial terhadap suku bunga deposito 3 bulan, maka tabel coefficients di bawah ini akan menunjukkan hasilnya. 


\begin{tabular}{|c|c|c|c|c|c|c|}
\hline \multicolumn{7}{|c|}{ Coefficients $^{\mathrm{a}}$} \\
\hline \multirow{2}{*}{\multicolumn{2}{|c|}{ Model }} & \multicolumn{2}{|c|}{$\begin{array}{l}\text { Unstandardized } \\
\text { Coefficients }\end{array}$} & \multirow{2}{*}{$\begin{array}{c}\text { Standardized } \\
\text { Coefficients } \\
\text { Beta }\end{array}$} & \multirow[t]{2}{*}{$\mathrm{t}$} & \multirow[t]{2}{*}{ Sig. } \\
\hline & & $\mathrm{B}$ & $\begin{array}{l}\text { Std. } \\
\text { Error }\end{array}$ & & & \\
\hline \multirow[t]{3}{*}{1} & (Constant) & -3.668 & 2.411 & & -1.521 & .163 \\
\hline & $\mathrm{m} 2$ & $2.542 \mathrm{E}-6$ & .000 & 1.004 & 3.386 & .008 \\
\hline & inflasi & .572 & .095 & 1.785 & 6.019 & .000 \\
\hline
\end{tabular}

Dari hasil analisa di atas dapat dilihat hubungan antara variable independen terhadap variable dependen. Dari nilai signifikansi yang nilainya lebih kecil dari 0,05 maka dapat dikatakan bahwa kedua variable inflasi dan jumlah uang yang beredar secara parsial berpengaruh secara signifikan terhadap suku bunga deposito 3 bulan. Model persamaan regresi dari hasil pengujian di atas: $\operatorname{lnt} 3=-3,668+2.542 E-6 M 2+0,572 \operatorname{Inf}$

\section{HASIL DAN PEMBAHASAN}

Dari hasil pengujian empirik di atas, baik mengenai pengaruh ekspektasi inflasi dan aktifitas perekonomian terhadap suku bunga deposito maupun mengenai hubungan ekspektasi inflasi di Indonesia dapat kita gambarkan dalam gambar berikut ini:

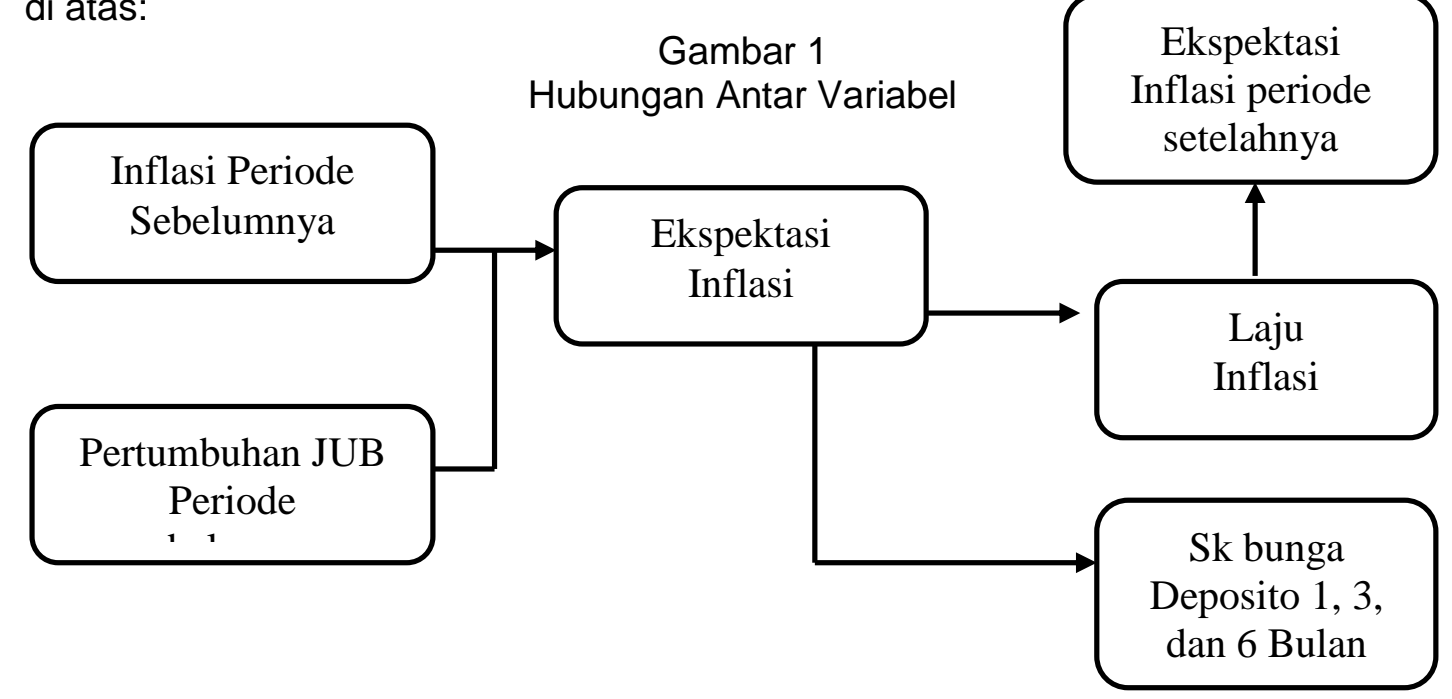

Dari gambar di atas dapat dijelaskan mengenai hubungan beberapa variabel. Informasi-informasi yang diperoleh dari variabel inflasi dan pertumbuhan jumlah uang beredar pada periode sebelumnya (triwulan sebelumnya) telah membentuk ekspektasi para pelaku pasar mengenai tingkat inflasi yang akan terjadi. Ekspektasi inflasi kemudian mereka terjemahkan dalam interaksi antara permintaan dan penawaran, sehingga ekspektasi inflasi yang telah mereka bentuk hampir mendekati tingkat inflasi aktual $\left(R^{2}\right.$ pada persamaan tabel 1 sangat besar, yaitu sebesar 0,884). Inflasi yang terbentuk oleh ekspektasi masyarakat ini akan digunakan lagi oleh masyarakat untuk membentuk ekspektasi inflasi mereka pada periode selanjutnya. 
Karena pengaruh ekspektasi inflasi lebih besar daripada pengaruh aktifitas perekonomian, dari hasil penelitian ini dapat disimpulkan bahwa suku bunga deposito 3 bulan dapat digunakan untuk melihat ekspektasi masyarakat, atau lebih tepatnya dapat digunakan untuk melihat tingkat inflasi ke depan (mengingat besarnya pengaruh ekspektasi inflasi terhadap suku bunga deposito).

\section{KESIMPULAN}

Tingkat laju inflasi ditentukan oleh kekuatan permintaan dan penawaran yang mencerminkan perilaku para pelaku pasar atau masyarakat. Salah satu faktor yang mempengaruhi perilaku masyarakat tersebut adalah ekspektasi mereka terhadap laju inflasi. Ekspektasi terhadap laju inflasi akan sangat terkait dengan informasi yang dimilikinya. Jenis informasi yang diterima akan bervariasi dan pola perilaku merekapun berbeda-beda dalam menyikapi mengenai suatu informasi yang sama. Ekspektasi terhadap laju inflasi akan didasarkan informasi-informasi yang terdapat jumlah uang beredar, bahkan tingkat inflasi sebelumnya.

Ekspektasi masyarakat terhadap inflasi di masa mendatang antara lain dapat dilihat dari perkembangan suku bunga nominal perbankan. Secara umum, suku bunga nominal mencerminkan tingkat suku bunga riil ditambah ekspektasi inflasi. Dengan asumsi bahwa tingkat suku bunga riil adalah konstan, maka suku bunga nominal merupakan fungsi dari ekspektasi inflasi. Tetapi, bagi perekonomian yang fluktuatif seperti Indonesia, tingkat suku bunga riil tidaklah konstan tetapi dipengaruhi oleh aktifitas perekonomian (business cycles). Berdasarkan model yang dikembangkan, ekspektasi inflasi dan kegiatan ekonomi mempunyai pengaruh yang besar dan signifikan terhadap tingkat suku bunga nominal yang diwakili oleh tingkat suku bunga deposito 3 bulan.

\section{DAFTAR PUSTAKA}

Bodie, A. Kane and A. Marcus, 2001, Investments 5Th edition. McGraw Hill/Irvin,Singapore.

Didy Laksmono R, et al. 2001. "Suku Bunga Sebagai Salah Satu Indikator Ekspektasi Inflasi." Buletin Ekonomi Moneter dan Perbankan. Edisi Maret 2000. UREM Bank Indonesia. Jakarta.

Edwards, Sebastian dan Mohsin S. Khan, 1985. Interest Rate Determination In Developing Countries: a Conceptual Framework. NBER Working Paper Series. Working Paper No. 1531.

Mishkin, Frederic S. 1981. "Are Market Forecast Rational?" The American Economic Review. Vol 71, No. 3.

Samuelson, Paul dan William Nordhaus. 1996. Makroekonomi. Terjemahan. Haris Munandar et al. Penerbit Erlangga. Jakarta. 